\title{
Milk Chemical Composition of Dairy Cows Fed Rations Containing Protected Omega-3 Fatty Acids and Fermented Rice Bran
}

\author{
Sudibya* \& S. H. Purnomo \\ Department of Animal Science, Faculty of Agriculture, Sebelas Maret University \\ Jln. Ir. Sutami 36 A, Surakarta 57126, Indonesia \\ (Received 18-09-2013; Reviewed 23-10-2013; Accepted 09-12-2013)
}

\begin{abstract}
The research was conducted to investigate the effect of ration containing protected omega-3 and fermented rice bran on chemical composition of dairy milk. The research employed 10 female PFH dairy cows of 2-4 years old with body weight $300-375 \mathrm{~kg}$. The research was assigned in randomized complete block design. The treatment consisted of $\mathrm{P} 0=$ control ration, $\mathrm{P} 1=\mathrm{P0}+20 \%$ fermented rice bran, $\mathrm{P} 2=\mathrm{P} 1+4 \%$ soya bean oil, $\mathrm{P} 3=\mathrm{P} 1+4 \%$ protected tuna fish oil and $\mathrm{P} 4=\mathrm{P} 1+4 \%$ protected lemuru fish oil. The results showed that the effects of fish oil supplementation in the rations significantly $(\mathrm{P}<0.01)$ decreased feed consumption, cholesterol, low density lipoprotein, lipids, and saturated fatty acids. Meanwhile, it increased milk production, content of high density lipoprotein, omega-3, omega- 6 and unsaturated fatty acids in the dairy cows milk. It is concluded that the inclusion of $4 \%$ protected fish oil in the rations can produce healthy milk by decreasing milk cholesterol and increasing omega-3 fatty acids content.
\end{abstract}

Key words: dairy milk, fermented rice bran, fish oil protected, omega-3 fatty acid

\section{ABSTRAK}

Penelitian ini bertujuan untuk menguji pengaruh ransum yang mengandung omega-3 terproteksi dan dedak padi fermentasi terhadap komposisi kimia susu sapi. Penelitian menggunakan 10 ekor sapi perah betina berumur 2-4 tahun dengan bobot badan 300-375 kg. Penelitian menggunakan rancangan acak kelompok. Perlakuan terdiri atas $\mathrm{P0}=$ ransum kontrol, $\mathrm{P} 1=\mathrm{P} 0+20 \%$ dedak padi fermentasi, P2= P1 + 4\% minyak kacang kedelai, P3= P1 + 4\% minyak ikan tuna terproteksi, dan P4= P1 + 4\% minyak ikan lemuru terproteksi. Hasil penelitian menunjukkan bahwa efek suplementasi minyak ikan dalam ransum secara nyata $(P<0,01)$ menurunkan konsumsi pakan, kolesterol, LDL $($ low density lipoprotein), lipid, dan asam lemak jenuh. Namun demikian, meningkatkan produksi susu, kandungan HDL (high density lipoprotein), omega-3, omega-6, dan asam lemak tidak jenuh dalam susu sapi. Dapat disimpulkan bahwa penambahan minyak ikan terproteksi sebanyak $4 \%$ dalam ransum mampu menghasilkan susu yang sehat dengan menurunkan kandungan kolesterol susu dan meningkatkan kandungan asam lemak omega-3.

Kata kunci: susu sapi, dedak padi fermentasi, minyak ikan terproteksi, asam lemak omega-3

\section{INTRODUCTION}

Dairy milk is a source of animal protein which is needed by the community at all age levels. Therefore, we need a dairy product that can meet the nutritional value of all age levels. Dairy milk product which is rich in omega-3 fatty acids and low in cholesterol is a breakthrough to produce healthy animal product. The content of omega- 3 is very beneficial for the children especially in infancy, while for adults are very useful for those who have heart problem high blood pressure and cholesterol.

${ }^{*}$ Corresponding author:

E-mail: sudibya_uns@yahoo.com
Recent research from O'Rourke (2013) found that supplementation of omega- 3 was able to active the process of autophagy, which is a kind of recycling mechanism that is able to increase the body's cell. Furthermore, it can increase cell resistance in order to slow cell aging. Therefore, we need to study dairy cows which produce milk containing high omega-3 and low cholesterol. These products can be made by manipulating the soap supplementation protected with extracts containing omega-3 fatty acids which mixed with fermented rice bran in rations. Research on milk products with high omega-3 fatty acids has not been much reported. Sudibya et al. (2013) reported that supplementation of tuna and lemuru fish oil in the rations can increased omega-3 fatty acids and decreased cholesterol of goats' 
milk. Therefore, the researchers assume that supplementation of fish oil on the ration of dairy cow will get the same impact.

Omega-3 fatty acids often found in marine fish mainly lemuru, tuna and shark. Lemuru fish when it is extracted will generate a lot of fish oil containing omega3 fatty acids especially EPA (eicosapentaenoic acid) $34.17 \%$ and DHA (docosahexaenoic acid) around $17.40 \%$ and fat content $6 \%$ and TDN $182 \mathrm{kcal} / \mathrm{kg}$ fish oil, while tuna fish will generate fish oil containing omega-3 fatty acids especially EPA (eicosapentaenoic acid) $33.6 \%$ to $44.85 \%$ and DHA (docosahexaenoic acid) around 14.64\% and $5.8 \%$ fat and $178 \mathrm{kcal}$ TDN/kg (Sudibya et al., 2008, 2011). Because of content differences between two fish, therefore it needs to be examined

A manipulation of fat metabolism in the rumen is intended to control antimicrobial effects of fatty acids to minimize disturbance of rumen fermentation. Therefore the highest fat level can be included in the diet. Secondly, it's to control biohidrogenation to increase the absorption of desired fatty acids to improve the nutritional quality of livestock products (Chillard, 1993). Fish oil supplementation in the diet should be in a particular done so as not to disrupt the activity of rumen microorganisms. Jenkins (1993) stated that the addition of fish oils in ruminant feed should not exceed $6 \%-7 \%$ of ration dry matter as it will affect rumen fermentation. Sudibya et al. $(2010,2011)$ stated that functions of omega-3 fatty acids in decreasing cholesterol levels in two ways namely 1) stimulates the excretion of cholesterol through the bile from the liver into the intestine and 2) stimulate the catabolism of HDL cholesterol by the liver back into bile acids and not regenerated again. It's excreted through feces. Dairy cows milk usually consumed by humans in a state of cooked, so, we need organoleptic (taste, odor and color). Furthermore, we need to examine the content of omega-3 fatty acids as well as fat oxidation products with peroxide levels and the levels of malonaldehyde.

In light of such issues, the study aims to produce feed formula of dairy cows which containing protected fish oil and fermented rice bran. The second purpose was to examine the milk chemical composition particularly omega-3 fatty acids and cholesterol.

\section{MATERIALS AND METHODS}

This research was experimental design conducted in Glagah village, Jatinom District, Klaten Regency. The laboratory analysis conducted in Veterinary Medicine Laboratory of Bogor Agricultural University, Chemistry Laboratory of Gadjah Mada University and Laboratory of Agriculture Technology and the Laboratory of Feed Nutrition, Department of Animal Husbandry, Sebelas Maret University, Surakarta.

\section{Rice Bran Fermentation}

Fermentation of rice bran was done by yeast with duration of $0,1.5,3$, and $4.5 \mathrm{~d}$. Furthermore, the fermented rice bran was analyzed proximate in order to reveal the content of crude protein and crude fiber.

\section{Formation of Fatty Acid Soap}

Protected fat products were made through a combination process of saponification and encapsulation of lemuru fish oil and tuna oil using 10\% NaOH, 10\% starch, and saturated $\mathrm{CaCl} 2$ solution. Saponification and encapsulation were done by heating lemuru and tuna fish oil at a temperature of $60-80 \mathrm{oC}$ for $10 \mathrm{~min}$ and then mixed with $10 \% \mathrm{NaOH}$ solution with stirring and $10 \%$ starch solution was added to form a paste of clay. Clumps were settled for one night in order to make it hard. Clumps of crystallized soap obtained by soaking with saturated $\mathrm{CaCl} 2$ solution for $2 \mathrm{~h}$. Fatty acid soap crystals formed was filtered and pressed then dried in the oven or in the sun. Fatty acid soap crystals that have been dried were used in the digestibility trials and the resistance from biohydrogenation process by rumen microbes.

\section{Experimental Design and Data Analysis}

The study was conducted as a randomized completely block design with 5 dietary treatments namely $\mathrm{P} 0=$ Control ration, $\mathrm{P} 1=\mathrm{P} 0+20 \%$ fermented rice bran replacing rice bran in the ration, $\mathrm{P} 2=\mathrm{P} 1+4 \%$ soya bean oil, $\mathrm{P} 3=\mathrm{P} 1+4 \%$ protected tuna fish oil, $\mathrm{P} 4=\mathrm{P} 1+4 \%$ protected lemuru fish oil and using 2 blocks of body weight as replications. The data were analyzed with analyses of variance (ANOVA) and were continued with orthogonal contrast test (Steel \& Torrie, 1980).

\section{Farming Management of Dairy Cows}

Farming of dairy cows carried out for 90 d. Feeding was given twice a day in the morning and evening. Milking was done also twice a day in the morning and afternoon. The amount of feed given was $20 \mathrm{~kg}$ of fresh forage and $9 \mathrm{~kg}$ concentrate per day per cow. Milk samples were first taken on day $21^{\text {th }}$ after feeding treatment, cooked at temperature of $60{ }^{\circ} \mathrm{C}$ and were analyzed in the laboratory. Analysis in the laboratory was taken three times on day $45^{\text {th }}, 60^{\text {th }}$, and $90^{\text {th }}$. The composition of the ration can be seen in Table 1, 2, and 3 .

\section{Parameter Analyses}

Variables measured were: cholesterol content of cooked dairy milk with the method of Kleiner \& Dotti (1962), lipid content of cooked dairy milk with the method of AOAC (2001), LDL (Low Density Lipoprotein) and HDL (High Density Lipoprotein) of cooked dairy milk with the method of Assman (1982), contents of linolenic fatty acid (omega-3) and linoleic fatty acid (omega-6) of dairy milk with the method of AOAC (1990).

\section{RESULTS AND DISCUSION}

\section{Consumption of Feed}

The lowest consumption of feed was in P4 $9.37 \mathrm{~kg}$ (DM/head/day), whereas the highest one was in P0 11.1 $\mathrm{kg} / \mathrm{head} /$ day. The complete data can be seen in Table 4 . 
Table 1. Ingredient of feed formula (\%)

\begin{tabular}{lcccccccc}
\hline \multicolumn{1}{c}{ Name } & Water & Ash & Crude protein & Crude lipid & Crude fiber & TDN & Ca & P \\
\hline King grass & 84.10 & 8.80 & 8.72 & 3.68 & 33.60 & 52.10 & 0.16 & 0.19 \\
Rice bran & 12.72 & 7.70 & 11.99 & 10.70 & 11.61 & 67.90 & 0.04 & 0.34 \\
Fermented rice bran & 12.97 & 2.59 & 14.20 & 5.58 & 8.10 & 69.40 & 0.24 & 0.32 \\
Cassava dregs & 12.97 & 2.59 & 2.20 & 5.58 & 24.10 & 54.40 & 0.24 & 0.32 \\
Coconut meal & 11.97 & 7.94 & 23.03 & 15.30 & 13.50 & 78.70 & 0.02 & 0.36 \\
Soya bean meal & 12.20 & 6.84 & 44.60 & 6.70 & 9.80 & 56.40 & 0.03 & 0.24 \\
Mineral premix & - & - & - & - & - & - & 50.00 & 25.00 \\
Tuna fish oil & & - & - & - & 5.80 & - & 178.00 & - \\
Lemuru fish oil & - & - & - & 6.00 & - & 182.00 & - & - \\
\hline
\end{tabular}

Source: *) Laboratory analysis on LAKFIP UGM (2010).

Table 2. Nutrient content of feed formula

\begin{tabular}{lrrrrc}
\hline Nutrient content & \multicolumn{1}{c}{ P0 } & \multicolumn{1}{c}{ P1 } & \multicolumn{1}{c}{ P2 } & \multicolumn{1}{c}{ P3 } & P4 \\
\hline Crude protein (\%) & 13.80 & 14.00 & 14.20 & 14.26 & 14.35 \\
TDN (kcal/kg) & 64.00 & 64.00 & 65.00 & 67.00 & 67.00 \\
Crude lipids (\%) & 4.82 & 5.02 & 5.02 & 5.02 & 5.02 \\
Crude fiber (\%) & 18.90 & 16.90 & 16.90 & 16.90 & 16.9 \\
Calcium (\%) & 2.58 & 2.58 & 2.59 & 2.58 & 2.58 \\
Phospor (\%) & 0.78 & 0.78 & 0.78 & 0.78 & 0.78 \\
Omega-3 (\%) & 0.00 & 0.00 & 0.12 & 3.13 & 3.15 \\
\hline
\end{tabular}

Note: $\mathrm{P} 0=$ Control ration, $\mathrm{P} 1=\mathrm{P} 0+20 \%$ fermented rice bran replacing rice bran in the ration, $\mathrm{P} 2=\mathrm{P} 1+4 \%$ soya bean oil, $\mathrm{P} 3=\mathrm{P} 1+4 \%$ protected tuna fish oil, $\mathrm{P} 4=\mathrm{P} 1+4 \%$ protected lemuru fish oil

The treatments had significant $(\mathrm{P}<0.01)$ difference on feed consumption. P0 (control), P1, and P2 treatments had lower feed consumption than those of P3 and P4 treatments, but among P0, P1, and P2 were not significantly different. This is due to the equal nutrition contained in the ration.

The addition of tuna fish oil (P3) and lemuru fish oil (P4) decreased feed consumption since fish oil serves as the source of energy in addition to the source of unsaturated fatty acids leads to the raise of TDN content in the feed. The increase of TDN would consequently improve rumen microbial growth and activity producing higher VFA as energy source for the host. High VFA production caused less feed was required to fulfill the animal requirement.

The effect of unsaturated fatty acid addition in the feed was decreasing production of methane $(\mathrm{CH} 4)$ and in the ratio of acetate to propionate formed in the rumen (Rebollar \& Blas, 2005). Oil or fat in the feed will immediately undergo lipolysis and biohydrogenation. The hydrogen used in the biohydreganation process of unsaturated fatty acids was the side product of synthesis of acetic and butyric acids (Tiven et al., 2011). The formation of methane gas from hydrogen and $\mathrm{CO} 2$ can be minimized as a result of hydrogen shifting to saturate the fat. Organic matter is the major component of dry matter. Ash contains mineral which does not have en-
Table 3. Composition of ration

\begin{tabular}{lccccc}
\hline & P0 & P1 & P2 & P3 & P4 \\
\hline King grass & 50 & 50 & 50 & 50 & 50 \\
Soya bean meal & 4 & 4 & 4 & 4 & 4 \\
Rice bran & 30 & 10 & 10 & 10 & 10 \\
Fermented rice & 0 & 20 & 20 & 20 & 20 \\
bran & & & & & \\
Yellow corn & 12 & 12 & 12 & 12 & 12 \\
Coconut meal & 4 & 4 & 4 & 4 & 4 \\
Soya bean oil & 0 & 0 & 4 & 0 & 0 \\
Tuna fish oil & 0 & 0 & 0 & 4 & 0 \\
Lemuru fish oil & 0 & 0 & 0 & 0 & 4 \\
Total & 100 & 100 & 104 & 104 & 104 \\
\hline
\end{tabular}

Note: $\mathrm{P} 0=$ Control ration, $\mathrm{P} 1=\mathrm{P} 0+20 \%$ fermented rice bran replacing rice bran in the ration, $\mathrm{P} 2=\mathrm{P} 1+4 \%$ soya bean oil, $\mathrm{P} 3=\mathrm{P} 1+4 \%$ protected tuna fish oil, $\mathrm{P} 4=\mathrm{P} 1+4 \%$ protected lemuru fish oil

Table 4. Average feed consumption and production of dairy milk

\begin{tabular}{ccc}
\hline \multirow{2}{*}{ Treatment } & \multicolumn{2}{c}{ Parameter } \\
\cline { 2 - 3 } & $\begin{array}{c}\text { Production of milk dairy } \\
\text { cow (L/head/day) }\end{array}$ & $\begin{array}{l}\text { Feed cunsumption } \\
\text { (kg DM/head/day) }\end{array}$ \\
\hline P0 & $8.147 \pm 0.106^{\mathrm{a}}$ & $11.190 \pm 0.121^{\mathrm{a}}$ \\
P1 & $8.520 \pm 0.330^{\mathrm{a}}$ & $11.090 \pm 0.163^{\mathrm{a}}$ \\
P2 & $8.800 \pm 0.199^{\mathrm{a}}$ & $10.800 \pm 0.199^{\mathrm{a}}$ \\
P3 & $9.360 \pm 0.178^{\mathrm{b}}$ & $9.500 \pm 0.100^{\mathrm{b}}$ \\
P4 & $9.500 \pm 0.100^{\mathrm{b}}$ & $9.370 \pm 0.178^{\mathrm{b}}$ \\
\hline
\end{tabular}

Note: $\mathrm{P} 0=$ Control ration, $\mathrm{P} 1=\mathrm{P} 0+20 \%$ fermented rice bran replacing rice bran in the ration, $\mathrm{P} 2=\mathrm{P} 1+4 \%$ soya bean oil, $\mathrm{P} 3=\mathrm{P} 1+4 \%$ protected tuna fish oil, $\mathrm{P} 4=\mathrm{P} 1+4 \%$ protected lemuru fish oil

ergy. So, the digestibility of organic matter is closely related to the energy content available in the feed (Orskov, 1987). 


\section{Production of Milk}

The milk production given different treatments is presented in Table 4. Fish oil supplementation had a significant $(\mathrm{P}<0.01)$ effect on the milk production. The productions of milk in P1 and P2 did not increase in comparison to the production in P0 due to the insignificant different in feed consumption. The addition of tuna fish oil (P3) and lemuru fish oil (P2) could increase the production of milk since fish oil serves not only as the source of unsaturated fatty acid but also the source of energy. Therefore, fish oil addition could increase feed consumption which eventually increased production of milk. This result was inline with the study of Fatahnia et al. (2008) that supplementation of fish oil in the diet could produce more milk than soybean oil.

\section{Lipid Content of Milk}

The lipid content of P0 was significantly $(\mathrm{P}<0.01)$ different with P3 and P4, but was not significantly different with P1 and P2 (Table 5). Treatment of P1 and P2 was significantly $(\mathrm{P}<0.01)$ different with $\mathrm{P} 3$ and P4. Abughazaleh et al. (2002) and Fatahnia et al. (2008) reported that addition of fish oil and soybean oil or its combination on the diets of dairy cows could increase milk fat composition. That was inline with this research that the addition of protected lemuru and tuna fish oil (P3 and P4) could increase lipids content of dairy cow milk. That was because fish oil is energy source and source of unsaturated fatty acids. It can increase lipids content of dairy cow milk. Suarez et al. (1996) reported that supplementation of polyunsaturated fatty acids in the ration can increase lipids content in the body tissue. Furthermore, Vahmani et al. (2013) found that supplementation of dairy cows with marine oils stimulates increasing fatty acids content of milk.

\section{Low Density Lipoprotein Content of Milk}

Low density lipoprotein content of P0, P1, and P2 was significantly $(\mathrm{P}<0.01)$ different with $\mathrm{P} 3$ and $\mathrm{P} 4$. However, it was not significantly different among P0, P1, and P2, also between P3 and P4 (Table 5). Sudibya et al. (2010) reported that supplementation of soya bean oil could not decrease LDL content of dairy milk. Meanwhile, in this research the addition of protected lemuru and tuna fish oil (P3 and P4) could decrease LDL content of dairy milk. That was because fish oil stimulates the excretion of cholesterol through the bile from the liver into the intestine. It was inline with Komari (1994) and Sinclair (1996) that supplementation of polyunsaturated fatty acids in the ration could decrease LDL content in the body tissue. In addition, Gebauer et al. (2007) and Shingfield et al. (2008) reported that feeding fish oil and marine oil decreased low density lipoprotein.

\section{High Density Lipoprotein Content of Milk}

High density lipoprotein content of P0 was significantly $(\mathrm{P}<0.01)$ different with $\mathrm{P} 3$ and $\mathrm{P} 4$, but was not significantly different with P1 and P2 (Table 5). Gebauer et al. (2007) and Shingfield et al. (2008) reported that feeding fish oil and marine oil increased high density lipoprotein. That finding was inline with this research that the addition of protected lemuru and tuna fish oil (P3 and P4) could increase HDL content of dairy milk. That was because fish oil stimulates the catabolism of HDL cholesterol by the liver back into bile acids and not regenerated again. It is excreted through feces. It can increase HDL content of dairy milk. Komari (1994) and Sinclair et al. (1996) reported that supplementation of polyunsaturated fatty acids in the ration could increase HDL content in the body tissue.

\section{Cholesterol Content of Milk}

Cholesterol content of P0 was significantly $(\mathrm{P}<0.01)$ different with P3 and P4, but was not significantly different with P1 and P2 (Table 5). Supplementation of soya bean oil (P2) did not decrease the content of cholesterol in dairy cow milk. That is in line with the result of research from Sudibya et al. (2010) which states that soya bean oil supplementation can not be used to decrease cholesterol levels. The addition of tuna and lemuru fish oil can decrease cholesterol content of dairy cow milk in P3 and P4. It was concurred with Sudibya et al. (2010, 2013) that cholesterol levels in dairy cows milk decrease due to the transfer of omega- 3 fatty acids. This can be explained that the omega-3 fatty acids work by stimulating the catabolism of HDL cholesterol to the liver back into bile acids and not regenerated again. It was excreted through feces. So that the cholesterol content in excreta

Table 5. Average lipids, low density lipoprotein (LDL), high density lipoprotein (HDL), and cholesterol content of dairy milk

\begin{tabular}{ccccc}
\hline \multirow{2}{*}{ Treatment } & \multicolumn{3}{c}{ Parameter } \\
\cline { 2 - 5 } & Lipids (\%) & LDL $(\mathrm{mg} / \mathrm{dl})$ & HDL $(\mathrm{mg} / \mathrm{dl})$ & Cholesterol $(\%)$ \\
\hline P0 & $3.340 \pm 0.140^{\mathrm{a}}$ & $37.380 \pm 0.967^{\mathrm{a}}$ & $62.620 \pm 0.967^{\mathrm{a}}$ & $0.186 \pm 0.019^{\mathrm{a}}$ \\
P1 & $3.366 \pm 0.169^{\mathrm{a}}$ & $36.280 \pm 1.010^{\mathrm{a}}$ & $63.720 \pm 1.010^{\mathrm{a}}$ & $0.170 \pm 0.020^{\mathrm{a}}$ \\
P2 & $3.823 \pm 0.263^{\mathrm{a}}$ & $36.270 \pm 0.950^{\mathrm{a}}$ & $63.730 \pm 0.951^{\mathrm{a}}$ & $0.163 \pm 0.021^{\mathrm{a}}$ \\
P3 & $4.016 \pm 0.142^{\mathrm{b}}$ & $25.190 \pm 0.932^{\mathrm{b}}$ & $74.810 \pm 0.932^{\mathrm{b}}$ & $0.132 \pm 0.009^{\mathrm{b}}$ \\
P4 & $4.023 \pm 0.264^{\mathrm{b}}$ & $25.150 \pm 0.853^{\mathrm{b}}$ & $74.850 \pm 0.853^{\mathrm{b}}$ & $0.124 \pm 0.007^{\mathrm{b}}$ \\
\hline
\end{tabular}

Note: Means in the same column with different superscript differ significantly $(\mathrm{P}<0.01)$. $\mathrm{P} 0=\mathrm{C}$-ntrol ration, $\mathrm{P} 1=\mathrm{P} 0+20 \%$ fermented rice bran replacing rice bran in the ration, $\mathrm{P} 2=\mathrm{P} 1+4 \%$ soya bean oil, $\mathrm{P} 3=\mathrm{P} 1+4 \%$ protected tuna fish oil, $\mathrm{P} 4=\mathrm{P} 1+4 \%$ protected lemuru fish oil. 
increased due to decreasing cholesterol levels in cow milk. Furthermore, insignificantly different between P3 and P4 was probably caused by the content of unsaturated fatty acids of protected lemuru and tuna fish oil is relatively the same so that the effects is similar.

\section{Omega-3 Fatty Acids (Linolenic) Content of Milk}

The omega-3 content of the milk was presented in Table 6. Omega-3 content of P0 significantly $(\mathrm{P}<0.01)$ different with P3 and P4, but was not significantly different with P1 and P2. However, it was not significantly different between P3 and P4. Baumgard et al. (2000) reported that concentration of total omega- 3 fatty acids increased in the milk of animals fed diet containing fish oil compared with the other oil supplementation. It means that protected unsaturated fatty acids did not undergo biohydrogenation process by rumen microbes. It was digested and absorbed in the intestine so that omega-3 fatty acids were deposited in milk. Goodridge et al. (2001) reported that supplementing dairy cow diets with a formaldehyde-treated flax product could increase a milk fat high in omega-3-linolenic acid. In addition, Fatahnia et al. (2008) found that the concentration of omega-3 fatty acids increased in milk of animals given diet containing fish oil compared with soybean oil or combination of fish oil and soybean oil.

\section{Omega-6 Fatty Acids (Linoleic) Content of Dairy Milk}

Omega-6 content of P0 was significantly $(\mathrm{P}<0.01)$ different with P3 and P4, but omega-3 content of P1 and P2 was not significantly different (Table 6). Sudibya et al. (2010) reported that supplementation of soya bean oil could not increase omega- 6 content of dairy milk. Meanwhile, in this research the addition of protected lemuru and tuna fish oil could increase omega- 6 content of dairy milk. It means that protected unsaturated fatty acids did not undergo biohydrogenation process by rumen microbes. It was digested and absorbed in the intestine so that the omega-6 fatty acids were deposited in milk. Komari (1994), Sinclair (1996) and Suarez et al. (1996) reported that supplementation of unsaturated fatty acids in the ration could decrease saturated fatty acids content in the animal tissue. Furthermore, Fatahnia et al.
(2008) reported that feeding fish oil and soybean oil and or its combination decreased the proportion of saturated fatty acids in milk fat.

\section{Unsaturated Fatty Acids Content of Dairy Milk}

Unsaturated fatty acids content of P0 was significantly $(\mathrm{P}<0.01)$ different with $\mathrm{P} 3$ and $\mathrm{P} 4$, but it was not significantly different unsaturated fatty acids content of P1 and P2 (Table 6). This research revealed that supplementation of fish oil in the diet could increase unsaturated fatty acids. That was inline with Estiasih (2009) who found that combination of fish oil and peanut oil may increase the levels of long chain unsaturated fatty acid. It can increase unsaturated fatty acids content of dairy milk. Goodridge et al. (2001) reported that milk linoleic acid was $10.3 \%$ significantly $(\mathrm{P}<0.05)$ higher in the milk of cows fed protected linola vs the control. Furthermore, Fatahnia et al. (2008) strengthened that feeding fish oil and soybean oil or its combination could increase unsaturated fatty acid concentrations. The incorporation of dietary unsaturated fats in milk would improve the nutritional value and possible human health benefits.

\section{Saturated Fatty Acids Content of Dairy Milk}

Saturated fatty acids content of P0 was significantly $(\mathrm{P}<0.01)$ different with $\mathrm{P} 3$ and $\mathrm{P} 4$, but was not significantly different with P1 and P2. Treatment of P1 and P2 were significanty $(\mathrm{P}<0.01)$ different with $\mathrm{P} 3$ and $\mathrm{P} 4$ (Table 6).

Fahtania et al. (2008) reported that feeding fish oil and soybean oil or its combination decreased the proportion of saturated fatty acids in milk fat. Furthermore, Estiasih (2009) reported that combination of fish oil and peanut oil may decrease the levels of long chain unsaturated fatty acid from $5.9 \%$ to $3.4 \%$. That was because fish oil is energy source and source of unsaturated fatty acids. It can decrease saturated fatty acids content of dairy milk. That was inline with the study of Komari (1994), Sinclair et al. (1996) and Suarez et al. (1996) who reported that supplementation of unsaturated fatty acids in the ration could decrease saturated fatty acids content in the body tissue.

Table 6. Average of omega-3, omega-6, unsaturated fatty acid, and saturated fatty acid content of dairy milk (\%)

\begin{tabular}{ccccc}
\hline \multirow{2}{*}{ Treatment } & \multicolumn{3}{c}{ Parameter } \\
\cline { 2 - 5 } & Omega-3 & Omega-6 & Unsaturated fatty acid & Saturated fatty acid \\
\hline P0 & $0.903 \pm 0.100^{\mathrm{a}}$ & $0.550 \pm 0.105^{\mathrm{a}}$ & $44.890 \pm 2.219^{\mathrm{a}}$ & $55.110 \pm 4.891^{\mathrm{a}}$ \\
P1 & $1.017 \pm 0.081^{\mathrm{a}}$ & $0.673 \pm 0.095^{\mathrm{a}}$ & $46.540 \pm 2.567^{\mathrm{a}}$ & $53.460 \pm 4.161^{\mathrm{a}}$ \\
P2 & $1.003 \pm 0.084^{\mathrm{a}}$ & $0.677 \pm 0.093^{\mathrm{a}}$ & $46.550 \pm 2.159^{\mathrm{a}}$ & $53.450 \pm 2.159^{\mathrm{a}}$ \\
P3 & $3.597 \pm 0.203^{\mathrm{b}}$ & $20.630 \pm 2.765^{\mathrm{b}}$ & $71.530 \pm 2.825^{\mathrm{b}}$ & $27.470 \pm 1.784^{\mathrm{b}}$ \\
P4 & $3.873 \pm 0.371^{\mathrm{b}}$ & $19.760 \pm 0.923^{\mathrm{b}}$ & $72.290 \pm 1.408^{\mathrm{b}}$ & $27.710 \pm 1.408^{\mathrm{b}}$ \\
\hline
\end{tabular}

Note: Means in the same column with different superscript differ significantly $(\mathrm{P}<0.01)$. P0= Control ration, $\mathrm{P} 1=\mathrm{P} 0+20 \%$ fermented rice bran replacing rice bran in the ration, $\mathrm{P} 2=\mathrm{P} 1+4 \%$ soya bean oil, $\mathrm{P} 3=\mathrm{P} 1+4 \%$ protected tuna fish oil, $\mathrm{P} 4=\mathrm{P} 1+4 \%$ protected lemuru fish oil. 


\section{CONCLUSION}

Supplementation of protected PUFA and fermented rice bran decreases feed consumption and increases production of cow milk. The supplementation of protected tuna and lemuru fish oil up to $4 \%$ in the fermented rice bran feed of dairy cows increases the content of omega3, omega- 6 and unsaturated fatty acids but it decreases the content of saturated fatty acids of cow milk.

\section{REFERENCES}

Abughazale, A. A.,D. J. Schingoete, A. R. Hippen, K. F. Kalschear, \& L. A. Whitlock. 2002. Fatty acids profiles of milk and rumen digest from cows fish oil, extruded soybean or their blend. J. Dairy Sci. 82:2266-2276. http://dx.doi. org/10.3168/jds.S0022-0302(02)74306-3

AOAC. 1990. Official Methods of Analysis of the Association of Official Analytical Chemists. Association of Official Analytical Chemist, Washington, DC

Assman, G. 1982. Lipid Metabolism and Atherosclerosis Schattaver. Stuffgart Verlag.

Baumgard, L. H., B. A. Corl, D. A. Dwyer, \& D. E. Bauman. 2000. Identification of the CLA isomer that inhibits milk fat synthesis. Am. J. Physiol. 278:R179-184.

Chillard, Y. 1993. Dietary fat and metabolism in ruminant adipose tissue, pigs and rodents: a review. J. Dairy Sci. 76:38973931. http://dx.doi.org/10.3168/jds.S0022-0302(93)77730-9

Estiasih, T. 2009. Fish Oil: Technology and Its Application to the Food and Health. First Edition. Graha Ilmu, Yogyakarta. P. 198.

Fahtania, F., A. Nikkah, M. J. Zamari, \& D. Kahrizi. 2008. Effect of dietary oil and soybean oil on milk production and composition of holstein cows in early lactation. Asian-Aust. J. Anim. Sci. 21:386-391.

Gebauer, S. K., T. L. Psota, \& P. M. Kris-Etherton. 2007. The diversity of health effects of individual trans fatty acid isomers. Lipids 42:787-799. http://dx.doi.org/10.1007/s11745007-3095-8

Goodridge, J., J. R. Ingails, \& G. H. Crow. 2001. Transfer of omega-3 linolenic acid and linoleic acid to milk fat from flaxseed or Linola protected with formaldehyde. Canadian J. Anim. Sci. 81: 525-532. http://dx.doi.org/10.4141/A01-024

Jenkins, T. C. 1993. Lipid metabolism in the rumen. J. Dairy Sci. 76: 3851-3863.

Kleiner, I. S. \& L. B. Dotti. 1962. Laboratory Instructions in Biochemistry. Sixth edition. The C. V. Mosby Company, New York.

Komari. 1994. Fish oil mikroencapsulation for omega-3 fatty acid fortification on the ration. Indonesian Gizi-Journal of the Indonesian Nutrition Association 19: 90-100.
O’Rourke, E. J., P. Kuballa, R. Xavier, \& G. Ruvkun. 2013. $\omega-6$ Polyunsaturated fatty acids extend life span through the activation of autophagy. Genes Development 27: 429-440. http://dx.doi.org/10.1101/gad.205294.112

Orskov, E. R. 1987. Protein Nutrition in Ruminant. Second Edition. Academic Press Limited, London. p: 3.

Rebollar, P. G. \& C. DeBlas. 2005. The Digestion of Whole Soybean in Ruminants. Soybean Association Rue duLuxemburg. Soyabaru@. Coditec.net.www.axa-europe org. Diakes tanggal 9 September 2007.

Sinclair, L. A., S. L. Cooper, S. Chikunya, R. G. Wilkinson, K. G. Hallett, M. Enser, \& J. D. Wood. 1996. Biohydrogenation of n-3 polyunsaturated fatty acids in the rumen and their effects on microbial metabolism and plasma fatty acid concentrations in sheep. J. An. Sci. 81: 239-248.

Shingfield, K. J., Y. Chillard, V. Toivenen, V. Kairenius, \& P. Givens. 2008. Trans fatty acids and bioactive lipids in ruminant milk. Adv. Exp. Med. Biol. 606:3-65. http://dx.doi. org/10.1007/978-0-387-74087-4_1

Steel, R. G. D. \& J. H. Torrie. 1980. Principles and Prosedures of Statistics. Mc Graw- Hill Inc., New York. Toronto. London.

Suarez, A. M., D. C. Ramires, M. J. Faus, \& A. Gil. 1996. Dietary long-chain polyunsaturated fatty acids influence tissue fatty acid composition in rats at weaning. J. Nutrition. 126:887-897.

Sudibya, T. Widyastuti, \& S. S. Santoso. 2008. Through the transfer of omega-3 and L- carnitine capsulilation its effect on chemical composition of goat meat. Inovasi, Jurnal Sains and Technology 1:108-115.

Sudibya. 2010. Rice bran fermentation technology and soya bean oil of transfer protection fatty acid of omega-3 of unsaturated fatty acids content of milk dairy cow. Journal of Rural and Development 1:42-57.

Sudibya, Darsono, \& P. Martatmo. 2011. Through the transfer of omega-3 and L- carnitine capsulation its effect on the chemical composition of meat of cattle. Journal of Rural and Development 2:62-84.

Sudibya \& S. H. Purnomo. 2013. Transfer of PUFA fatty acid protected and carnitin precursor on the ration of chemical composition of dairy goat milk. Open Journal of Animal Sciences 3: 225-229. http://dx.doi.org/10.4236/ ojas.2013.33033

Tiven, N. C., L. M. Yusiati, Rusman, \& U. Santosa. 2011. Protection of unsaturated fatty acids in crude palm oil from sheep microbial activity in vitro. Med. Pet. 34: 42-49. http:// dx.doi.org/10.5398/medpet.2011.34.1.42

Vahmani, P., A. H. Freeden, \& K. E. Glover. 2013. Effect of supplementation with fish oil or microalgae on fatty acid composition of milk from cows managed in confinement or pasture systems. J. Dairy Sci. 96: 6660-6670. http://dx.doi. org/10.3168/jds.2013-6914 